Rocznik Przektadoznawczy $17 \begin{aligned} & 0 \\ & 0 \\ & \text { Studia nad teoria, praktyka i dydaktyka przekładu }\end{aligned}$ ISSN 1896-4362

\title{
Targi Europejskiego Programu Studenckich Praktyk Zawodowych w Barcelonie
}

DOI: http://dx.doi.org/10.12775/RP.2016.019

Szóstego lutego 2015 roku na Uniwersytecie Autonomicznym w Barcelonie (Universitat Autònoma de Barcelona) odbyły się targi Europejskiego Programu Studenckich Praktyk Zawodowych - EGPS, których zadaniem jest stworzenie systemu praktyk studenckich dla studentów studiów drugiego stopnia specjalizacji tłumaczeniowych, a w przyszłości również studentów studiów licencjackich (Kwiatek, Zabrocka 2014). Celem targów było rozwijanie współpracy pomiędzy uczelniami kształcącymi przyszłych tłumaczy oraz firmami tłumaczeniowymi.

Targi były zorganizowane w taki sposób, aby umożliwić firmom dokładne zapoznanie się ze sposobem organizacji staży EGPS oraz zapewnić nawiązanie bezpośrednich kontaktów między firmami i uczelniami, które biorą udział w programie EGPS, zarówno w charakterze głównych partnerów, jak i uczelni stowarzyszonych.

\section{Wykład prof. Dona Kiraly'ego}

Same targi były częścią konferencji, która odbyła się 6 lutego. Dzień rozpoczął się od prelekcji prof. Dona Kiraly'ego z Uniwersytetu Johanna Gutenberga w Moguncji (Johannes Gutenberg-Universität Mainz) zatytułowanej From the Racetrack to the Crosscountry Trail: Bringing the Workplace into the Curriculum. Wykład poruszał tematykę kształcenia studentów przekładu w sposób zadaniowy, polegający na przydzielaniu im rzeczywistych zadań, z jakimi zetkną się w pracy po ukończeniu studiów. Jak mówił Kiraly, studenci powinni uczyć się przekładu przez faktyczne uczestnictwo w akcie tłumaczenia. Ilość instrukcji i wskazówek, którą otrzymują od prowadzącego, powinna być minimalna. Studenci uczestniczący w projektach tłumaczeniowych w grupach sami powinni się w te grupy zorganizować, wybrać spośród siebie kierownika projektu, terminologa oraz przydzielić sobie role tłumaczy i korektorów. Samodzielnie też powinni dokonać wyboru narzędzi tłumaczeniowych, zasobów leksykograficznych czy ustalić terminy zakończenia poszczególnych 
etapów pracy. Zadaniem nauczyciela przekładu powinno być natomiast wybranie tekstów i przydzielenie ich studentom, udzielanie odpowiedzi na ewentualne pytania, które pojawią się w trakcie pracy nad projektem, odesłanie studentów do odpowiednich źródeł i specjalistów w danej dziedzinie oraz ocena tłumaczenia. Ta zaś powinna być ustalona pod kątem poprawności językowej, estetycznej (formatowanie, edycja tekstu) oraz technicznej (właściwy format plików). Pod uwagę należy również brać sprawność funkcjonowania każdej grupy studentów jako potencjalnej firmy tłumaczeniowej, a zatem takie kwestie jak m.in. dotrzymywanie terminów i współpraca w grupie. Kiraly sugeruje, że studenci powinni otrzymywać do wykonania rzeczywiste zadania/zlecenia, pochodzące od organizacji pozarządowych, wolontariackich czy samorządów lokalnych. Idealnym rozwiązaniem jest również publikacja tłumaczeń wykonanych przez studentów na stronach internetowych i wymienienie osób tłumaczących z imienia i nazwiska. Działa to w sposób bardzo motywujący studentów, którzy czują się bardziej odpowiedzialni za jakość wykonywanego tłumaczenia. Dodatkowo taka publikacja może im pomóc w znalezieniu pracy bądź - jeśli zdecydują się na karierę badacza - będzie składać się na ich dorobek naukowy i tłumaczeniowy. W czasie wykładu podkreślano także fakt, że praktyki tłumaczeniowe powinny zostać włączone do programu nauczania na studiach, gdyż umożliwiają one studentom pracę $\mathrm{w}$ profesjonalnym środowisku tłumaczeniowym i pozwalają im wykonywać rzeczywiste zadania tłumaczeniowe (Kiraly, Piotrowska 2014). Praktyki stanowią zatem dopełnienie i uzupełnienie edukacji akademickiej, która w sferze praktycznej powinna wzorować się właśnie na takich stażach.

Wykład spotkał się z bardzo dużym zainteresowaniem zarówno ze strony uczelni, jak i przedstawicieli firm tłumaczeniowych, które były bardzo pozytywnie zaskoczone sugerowaną zmianą podejścia do nauczania przekładu. Edukacja na poziomie akademickim kojarzyła im się zazwyczaj z teorią, natomiast zastosowanie takich metod nauczania przez uczelnie specjalizujące się w kształceniu tłumaczy dostarczyłoby firmom tłumaczeniowym potencjalnych pracowników, którzy są doskonale przygotowani do pracy w zawodzie tłumacza.

Po wykładzie odbyła się prezentacja programów Agora oraz Elia, które są także systemami praktyk i staży studenckich. Agora ${ }^{1}$, podobnie jak EGPS, jest finansowana przez Komisję Europejską i stanowi element sieci European Master's in Translation. Agora to projekt trzyletni, koordynowany przez Uniwersytet Boloński. Ma bardzo zaawansowaną technologicznie bazę staży

${ }^{1}$ https://www.academic-projects.eu/agora/Pages/Project.aspx (dostęp: 27 kwietnia 2015). 
i pracodawców, która pozwala na wybór różnorodnych kryteriów wyszukiwania. Obecnie baza jest na etapie testowania.

Elia $^{2}$ jest europejskim stowarzyszeniem firm sektora usług językowych. Działa na rynku od ponad 10 lat. Podobnie jak EGPS i Agora, jest organizacją skupiającą studentów, firmy sektora usług językowych oraz uczelnie kształcące przyszłych tłumaczy. Obecnie w jej bazie zarejestrowanych jest 185 firm, 35 uczelni oraz 115 studentów.

\section{Warsztaty}

Po prezentacji programów Agory i Eli, uczestnicy (czyli przedstawiciele uczelni i firm tłumaczeniowych) zostali podzieleni na cztery grupy, które prowadziły dyskusje na następujące tematy:

1. Włączenie staży do programów nauczania,

2. Współpraca pomiędzy uczelniami i firmami,

3. Rola opiekuna staży,

4. Staże on-line.

Warsztaty umożliwiły przedstawicielom firm tłumaczeniowych oraz nauczycielom akademickim pierwszy bezpośredni kontakt, wymianę opinii oraz oczekiwań, co przyczyniło się do wyciągnięcia obustronnych i pełniejszych wniosków z dyskusji. Firmy tłumaczeniowe przyznały, że preferują dłuższe praktyki studenckie, gdyż wykształcenie należytych kompetencji u studenta zabiera im sporo czasu i tylko odpowiednio długi czas praktyk pozwala im zobaczyć efekty pracy ze stażystą, a także umożliwia zaangażowanie studenta do różnorodnych zadań. Zdaniem przedstawicieli firm minimalna długość praktyk to trzy miesiące, optymalna długość to pół roku. Wielu z nich uważało, że powinno się stworzyć studentom możliwość odbywania rocznych praktyk $w$ trakcie roku akademickiego. Preferencje uczelni dotyczące tego, kiedy student powinien wyjechać na praktyki, są różne. Dla większości uczelni najlepszym czasem na tego typu przedsięwzięcie jest okres wakacji, ale np. Uniwersytet Genewski chętnie wysyła swoich studentów na praktyki w drugim półroczu, z kolei UCL - w okresie od września do grudnia. Zarówno firmy, jak i uczelnie uznały, że bardzo ważna jest rola opiekuna praktyk, z którym student powinien mieć regularny kontakt, choćby mailowy lub przez Skype. Wymiana maili lub rozmowa powinny się odbywać przynajmniej co dwa tygodnie, aby opiekun był regularnie informowany o postępach

${ }^{2}$ http://www.elia-association.org/ (dostęp: 27 kwietnia 2015). 
praktyk, a także o pojawiających się problemach. Bardzo istotnym zagadnieniem poruszonym w dyskusji były finanse, a dokładnie - wsparcie finansowe studentów odbywających praktyki. Nauczyciele akademiccy uświadomili przedstawicielom firm, że studenci jedynie przez trzy miesięce otrzymują grant z puli Erasmus w kwocie od 400 do 600 euro (w zależności od kraju, do którego wyjeżdżają). Wiele firm zadeklarowało, że są w stanie wygospodarować stypendium dla studenta po ukończeniu przez niego 3-miesięcznych praktyk bądź też, w sytuacji gdyby student chciał lub musiał wrócić do kraju, zgadzają się na współpracę on-line. Niektóre firmy zaznaczyły, że już teraz wiele staży odbywa się u nich on-line.

\section{Targi}

Po części warsztatowej odbyły się targi. Nie były to targi typowo branżowe, gdyż to nie firmy tłumaczeniowe, a uczelnie miały przygotowane stanowiska i prezentowały swoją ofertę dotyczącą kształcenia przyszłych tłumaczy. Nie były to też targi edukacyjne, gdyż głównymi adresatami nie byli studenci (choć oni także mogli i brali w nich udział), a firmy tłumaczeniowe, które miały możliwość zapoznania się z potencjałem edukacyjnym uczelni, profilami, kompetencjami i oczekiwaniami studentów specjalizacji tłumaczeniowej. W targach uczestniczyło 13 uczelni z całej Europy, wśród których byli zarówno partnerzy EGPS, tj. Salford University, Uniwersytet Pedagogiczny w Krakowie, Universitat Autònoma de Barcelona, Johannes Gutenberg-Universität Mainz, jak i uczelnie stowarzyszone w projekcie EGPS: Comillas Pontifical University, University of Stirling, Universitat Ramon Llull, University College London, Universitat de Vic, University of Exeter, Université de Genève, Universita di Trieste i London Metropolitan University.

Wśród firm, które przybyły, żeby zapoznać się z ofertą uczelni, znalazły się: CPSL, iDISC, LocTeam, Montero, Nova, QuickSilver, TeleWorld, Tradeus, Traducciones Castilla i Urban. Większość z nich ma swoje siedziby w Hiszpanii, ale niektóre, jak np. CPSL, mają swoje biura również w innych krajach.

Pracownicy każdej z firm mieli możliwość podejścia do stanowiska uczelni i zapoznania się z jej ofertą edukacyjną, mogli także odbyć 10-15-minutową rozmowę z przedstawicielem uczelni (zazwyczaj opiekunem praktyk).

W międzyczasie Don Kiraly oraz Sascha Hofmann z Uniwersytetu w Moguncji rejestrowali zainteresowane firmy w bazie pracodawców EGPS. Baza zyskała w ostatnim czasie nową formę. Dla przedstawicieli uczelni partnerskich oraz koordynatora EGPS - Skills Cfa zostały stworzone konta admi- 
nistratorów bazy EGPS. Mogą oni zapisywać do bazy uczelnie stowarzyszone w projekcie EGPS, firmy tłumaczeniowe, które chcą zaoferować praktyki, oraz studentów, którzy są zainteresowani odbyciem praktyk. Po rejestracji w bazie firmy tłumaczeniowe mogą samodzielnie aktualizować swoje profile i oferty praktyk, natomiast studenci mają możliwość przeglądania aktualnych propozycji. Uczelnie stowarzyszone w projekcie uzyskują dostęp do bazy pracodawców, podobny do tego, jaki mają uczelnie partnerskie w projekcie EGPS (nie mają jednak kont administratora). Warunkiem ich przystąpienia do projektu EGPS jest wprowadzenie do niego nowych partnerów biznesowych, a zatem dodanie do bazy pracodawców EGPS firm, z którymi współpracują i w których studenci mogliby odbyć praktyki tłumaczeniowe. Interfejs nowej bazy jest bardzo przejrzysty, a ona sama jest łatwa w obsłudze i nawigacji zarówno dla administratorów (uczelni partnerskich EGPS) i firm tłumaczeniowych, jak i dla samych studentów.

\section{Podsumowanie}

Targi EGPS były doskonałą okazją do zacieśnienia więzi między światem nauki i biznesu. Pozytywna ocena i komentarze, które organizatorzy targów otrzymali od uczestników, zwłaszcza zaś firm tłumaczeniowych, świadczą o tym, że formuła targów, która umożliwia przedsiębiorstwom dokładne zapoznanie się nie tylko $\mathrm{z}$ ofertą edukacyjną uczelni, ale również z samym systemem organizacji praktyk, dokumentacją, sprawami formalnymi, jak finansowanie praktyk czy wymogami uczelni dotyczącymi długości praktyk, pozwala firmom tłumaczeniowym na dopasowanie ofert do potrzeb uczelni i studentów. Z kolei zapoznanie się z oczekiwaniami pracodawców umożliwia uczelniom dostosowanie programów studiów do potrzeb rynku usług tłumaczeniowych i kształcenie tłumaczy, którzy oprócz znajomości teorii będą przede wszystkim doskonałymi praktykami w swoim zawodzie.

\section{Literatura}

Kiraly, D., 2015, From the Racetrack to the Crosscountry Trail: Bringing the Workplace into the Curriculum, [wykład w trakcie targów EGPS w Barcelonie], 6 lutego 2015.

Kiraly, D., Piotrowska M., 2014, „Towards an Emergent Curriculum Development Model for the European Graduate Placement Scheme", [w:] Pi- 
xel (red.) Conference Proceedings: International Conference The Future of Education $4^{\text {th }}$ Edition 2014, s. 368-373.

Kwiatek, E., Zabrocka M., 2014, „EGPS-nowe możliwości na drodze kształcenia przyszłych tłumaczy", [w:] Rocznik Przekładoznawczy. Studia nad teoria, praktyka i dydaktyka przekładu, t. 9, s. 351-354.

Ewelina Kwiatek i Monika Zabrocka Uniwersytet Pedagogiczny im. KEN w Krakowie evelyn.kwiatek@gmail.com monika.zabrocka@gmail.com 